\title{
AN IMPROVED METHOD FOR THE PRODUCTION OF ANTISERA TO G1m ALLOTYPES
}

\author{
Tetsuko KISHIDA and Yoshihiro TAMAKI \\ Department of Forensic Medicine, Medical College of Oita, \\ Hasama-cho, Oita 879-56, Japan
}

\begin{abstract}
Summary An improved method is described for the production of rabbit anti-Gm sera using IgG subclasses isolated by $\mathrm{pH}$ gradient elution from protein A-Sepharose. The production rates of anti-G1m(x) and antiG1m(f) were increased by immunization with Fc fragments of $\operatorname{IgG}(\mathrm{a}, \mathrm{x})$ and $\mathrm{F}\left(\mathrm{ab}^{\prime}\right)_{2}$ fragments of $\operatorname{IgG} 1(\mathrm{a}, \mathrm{f})$, respectively.
\end{abstract}

\section{INTRODUCTION}

As a first step to promote the routine use of Gm-typing in forensic and genetic studies, a method has recently been reported for preparing rabbit anti-Gm sera using purified normal IgG subclasses as immunogens (Tamaki et al., 1981). These heteroantisera-anti-G1m(x), anti-G1m(f), anti-G3m( $\left.b^{1}\right)$, anti-G3m(t), and anti-G3m(g) -can distinguish the $9 \mathrm{Gm}$ phenotypes in the Japanese population. The method appeared easily accessible to all interested workers as it utilized normal IgG instead of myeloma proteins. However, the problem of raising the production rates of anti-G1m(x) and anti-G1m(f) remained to be solved. The present paper briefly reports an improvement on the previous method.

\section{MATERIALS AND METHODS}

Isolation of $\mathrm{IgG}$. Human plasma unsuitable for clinical use was obtained from a Japan Red Cross blood center. Sera were separated and Gm-typed by the conventional hemagglutination inhibition technique using anti-D-coated group $O$ cells and specific anti-Gm sera. The anti-D, anti-Gm sera, and a panel of standard Gm sera were generously provided by Prof. H. Matsumoto. Rabbit anti-Gm sera produced in our laboratory were also used. IgG of appropriate $\mathrm{Gm}$ type was isolated by ammonium sulfate precipitation at $35 \%$ saturation followed by chromatography on a DE-52 (Whatman) column. The eluate obtained with $0.01 \mathrm{~m}$ phosphate buffer (PB), pH 7.6, was concentrated by ultrafiltration, dialyzed against distilled water, 
lyophilized, and stored at $4^{\circ} \mathrm{C}$ until use. Its purity was checked by immunoelectrophoresis using anti-human serum (CAPPEL) and anti-IgG (produced in our laboratory).

Isolation of $\operatorname{IgG}$ subclasses. IgG subclasses were isolated by the method of Duhamel et al. (1979). Two hundred milligrams of IgG in $10 \mathrm{ml}$ of $0.15 \mathrm{M}$ citratephosphate buffer (CPB), $\mathrm{pH} 7.0$, were applied to a $1.5 \times 10 \mathrm{~cm}$ column of protein A-Sepharose CL-4B (Pharmacia). The effluent contained pure IgG3 as demonstrable by Gm-typing. The protein A-bound IgG (hereafter referred to as IgG1rich $\mathrm{IgG}$ ) was eluted with a $\mathrm{pH}$ gradient of $\mathrm{CPB}$ generated by a series of 3 equivolume chambers containing $0.15 \mathrm{M} \mathrm{CPB}$ (pH 5.0), 0.15 M CPB (pH 4.5), and $0.1 \mathrm{M}$ citric acid $(\mathrm{pH} 2.2)$, respectively. Two overlapping peaks were obtained, the first being enriched for IgG2 and the second for IgG1. This was confirmed by Gmtyping. In order to minimize the contamination of the subclasses by each other, only the fractions (hereafter referred to as $\operatorname{IgG} 2$ and $\operatorname{IgG} 1$, for convenience) corresponding to the first half of the first peak and the second half of the second peak were pooled and kept frozen until used.

Isolation of Fc fragments. Fc fragments were prepared by the method of Porter (1959) and Michaelsen and Natvig (1971) with slight modification. Two hundred milligrams of IgG1 of $\mathrm{Glm}(\mathrm{a}, \mathrm{x})$ type were incubated with $2 \mathrm{mg}$ papain (Sigma) in $0.1 \mathrm{M} \mathrm{PB}, \mathrm{pH} 7.0$, containing $0.01 \mathrm{M}$ L-cysteine monohydrochloride and $0.002 \mathrm{M}$ ethylenediamine tetraacetic acid disodium salt at $37^{\circ} \mathrm{C}$ for $30 \mathrm{~min}$. The digest was dialyzed against $0.01 \mathrm{M} \mathrm{PB}, \mathrm{pH} 7.6$, and applied to a $1.5 \times 10 \mathrm{~cm}$ DE-52 column. After washing with the same buffer, the bound $F c$ fragments were eluted with $0.2 \mathrm{M}$ $\mathrm{PB}, \mathrm{pH} 7.6$, and stored at $-20^{\circ} \mathrm{C}$ after concentration and sterile filtration. The purity of the $\mathrm{Fc}$ fragment preparation was checked by immunoelectrophoresis using specific anti-IgG, anti-Fab (Hoechst), and anti-Fc antiserum (Hoechst).

Isolation of $F\left(a b^{\prime}\right)_{2}$ fragments. A slight modification of the method of Hudson and Hay (1980) was used. Three milligrams of pepsin were added to $5 \mathrm{ml}$ of $2 \%$ solution of $\operatorname{IgGl}$ of $\mathrm{Glm}(\mathrm{a}, \mathrm{f})$ type in $0.1 \mathrm{M}$ sodium acetate buffer, $\mathrm{pH} 4.5$. The mixture was incubated at $37^{\circ} \mathrm{C}$ for $18 \mathrm{hr}$. The peptic digest was adjusted to $\mathrm{pH} 7.0$ with $1 \mathrm{M} \mathrm{NaOH}$, dialyzed against $0.1 \mathrm{M} \mathrm{PB}, \mathrm{pH} 7.0$, and subjected to affinity chromatography on protein A-Sepharose CL-4B to remove the $\mathrm{Fc}^{\prime}$ fragments and undigested IgG1. The effluent containing $F\left(a b^{\prime}\right)_{2}$ fragments was concentrated, filtered sterile, and kept at $-20^{\circ} \mathrm{C}$ until use. Its purity was tested by immunoelectrophoresis.

Immunization. Anti-G1m(x) serum was produced in the light of previous work (Giesen et al., 1974; Goosen et al., 1981). The rabbits were immune-paralyzed with an intravenous injection of $10 \mathrm{mg} \operatorname{IgG} 2(\mathrm{n})$ from which aggregated protein had been removed by ultracentrifugation. Three days later $1 \mathrm{mg} \mathrm{Fc}$ fragments of $\operatorname{IgGl}(\mathrm{a}, \mathrm{x})$ mixed with Freund's complete adjuvant was given intramuscularly and subcutaneously. The rabbits were boosted once a month with Fc fragments. The intravenous administration was only repeated if no precipitating antibody against IgG

Jpn. I. Human Genet. 
was detected. Three weeks after the first and 1 week after each booster injection, the animals were test-bled.

Immunization to $\mathrm{G} 1 \mathrm{~m}(\mathrm{f})$ was carried out without inducing unresponsiveness. Three milligrams of $\mathrm{F}\left(\mathrm{ab}^{\prime}\right)_{2}$ of $\operatorname{IgG} 1(\mathrm{a}, \mathrm{f})$ emulsified in Freund's complete adjuvant were administered intramuscularly and subcutaneously. One or two booster injections were given at intervals of a month. The animals were exsanguinated one week after the last injection.

Testing for antibody. The procedure used was essentially the same as that described in the preceding paper (Tamaki et al., 1981). Rabbit antisera were inactivated by heating at $56^{\circ} \mathrm{C}$ and absorbed with a mixture of group $\mathrm{O}, \mathrm{A}$, and $\mathrm{B}$ red cells, and subsequently with one-third its volume of $1 \% \mathrm{IgG}$ in saline negative for the $\mathrm{Gm}$ factor under study. The absorbed sera were tested for anti-Gm antibodies by the conventional hemagglutination inhibition method.

\section{RESULTS AND DISCUSSION}

Table 1 compares the results of the present and previous studies. As noted earlier, the Fc fragments of type Gm(a,x,g) IgG1-rich IgG were successfully used to produce anti-G1m(x) antibody after immunization experiments with intact molecules of IgG had ended in failure (Tamaki et al., 1981). However, immunization of a total 7 rabbits with the $\mathrm{Fc}$ fragments over a one-year period thereafter resulted in no production of anti-G $1 \mathrm{~m}(\mathrm{x})$. It has been shown that $\mathrm{IgG} 1$ is very low immunogenic in rabbits, but that IgG1 subclass-specific antisera can be produced by immunization following induction of unresponsiveness to the other subclasses (Spiegelberg and Weigle, 1968; Giessen et al., 1974; Goosen et al., 1981). With this and our experience in mind, 8 rabbits were injected first with IgG2 protein to suppress the production of antibodies against the common antigens on the $\operatorname{IgG}$ molecule. Next, the animals were immunized with Fc fragments of IgG1(a,x) instead of IgG1-rich IgG. This was successful in 2 rabbits and appears promising.

In order to increase the production rate of anti-G1m(f) antibody, rabbits were immunized with $\mathrm{F}\left(\mathrm{ab}^{\prime}\right)_{2}$ fragments of the IgG1 $(\mathrm{a}, \mathrm{f})$ subclass in place of the IgG1-rich $\operatorname{IgG}\left(\mathrm{a}, \mathrm{f}, \mathrm{b}^{1}, \mathrm{~b}^{3}\right)$ used in the previous experiments. This gave remarkably good results.

Table 1. Production of anti-Glm(x) and anti-Glm(f) sera.

\begin{tabular}{llcr}
\hline $\begin{array}{c}\text { Antibody } \\
\text { sought }\end{array}$ & \multicolumn{1}{c}{ Immunogen (Gm type) } & $\begin{array}{c}\text { Production } \\
\text { rate }\end{array}$ & $\begin{array}{c}\text { Antibody } \\
\text { titer }\end{array}$ \\
\hline Anti-GIm(x) & IgGl-rich IgG(a,x,g) & $0 / 6$ & - \\
& $\begin{array}{l}\text { Fc(a,x) of IgGl-rich IgG(a,x,g) without } \\
\text { tolerance induction }\end{array}$ & $1 / 7$ & 8 \\
& Fc(a,x) of IgGl(a,x) with tolerance induction & $2 / 8$ & 4 \\
Anti-Glm(f) & IgGl-rich IgG(a,f, $\left.\mathrm{b}^{1}, \mathrm{~b}^{3}\right)$ & $2 / 6$ & 256 \\
& $\mathrm{~F}\left(\mathrm{ab}^{\prime}\right)_{2}$ of IgGl(a,f) & $7 / 11$ & 64 \\
\hline
\end{tabular}


It is a pitty, however, that the anti-G1m antibodies have low titers compared with the anti-G3m.

Since some of the anti-D sera of different Gm specificities are practically unavailable, it is necessary that an alternative Gm-typing method be developed for routine use. This requires specific antibodies with much higher titers than can be expected from the rabbit antisera so far produced. Therefore, the introduction of monoclonal antibodies may be in order. A study in that direction is in progress.

Acknowledgments We wish to thank Prof. H. Matsumoto of Osaka Medical School for providing anti-D sera, anti-Gm sera, and a panel of standard Gm sera.

This work was supported in part by Grant in Aid for Developmental Scientific Research Nos. 00537013 and 56570244 from the Ministry of Education, Science and Culture of Japan.

\section{REFERENCES}

Duhamel, R.C., Schur, P.H., Brendel, K., and Meezan, E. 1979. pH gradient elution of human IgG1, IgG2 and IgG4 from protein A-Sepharose. J. Immunol. Methods 31: 211-217.

Giessen, M. van, Lange, B. de, and Lee, B. van der. 1974. The production of precipitating antiglobulin reagents specific for the subclasses of human IgG. Immunology 27: 655-663.

Goosen, P.C.M., Beekhuizen, S. van, Droogh, C., and Lange, G. de. 1981. Preparation of antibodies against subclasses of human IgG. J. Immumol. Methods 40: 339-344.

Hudson, L., and Hay, F.C. 1980. Pepsin digestion. In Practical Immunology, 2nd Ed., Blackwell Scientific Publications, Oxford, pp. 196-199.

Michaelsen, T.E., and Natvig, J.B. 1971. Isolation and characterization of IgG subclass proteins and $\mathrm{Fc}$ fragments from normal human IgG. A method for utilizing 'non a' and 'non $\mathrm{g}$ ' as genetic markers. Immunochemistry 8: 235-242.

Porter, R.R. 1959. The hydrolysis of rabbit $\gamma$-globulin and antibodies with crystalline papain. Biochem. J. 73: 119-126.

Spiegelberg, H.L., and Weigle, W.O. 1968. The production of antisera to human $\gamma$ G subclasses in rabbits using immunological unresponsiveness. J. Immunol. 101: 377-380.

Tamaki, Y., Kishida, T., Shibata, K., Takahashi, N., and Fukuda, M. 1981. Preparation of anti$\mathrm{Gm}$ sera by immunization of rabbits with protein A-fractionated normal IgG proteins from Japanese: Further study. J. Immunol. Methods 45: 177-182. 